UDK 811.162.1’373.45“18“

Izvorni znanstveni rad

Rukopis primljen 6. II. 2020.

Prihvaćen za tisak 2. XI. 2020.

doi.org/10.31724/rihjj.47.1.8

\author{
Ewa Woźniak \\ University of Lodz \\ U1. Pomorska 171/173, PL-90-236 Łódź \\ orcid.org/0000-0002-0784-6178 \\ ewa.wozniak@uni.lodz.pl \\ Rafał Zarębski \\ University of Lodz \\ U1. Pomorska 171/173, PL-90-236 Łódź \\ orcid.org/0000-0003-1918-2169 \\ rafal.zarebski@uni.lodz.pl
}

\title{
THE NAPOLEONIC CODE AND POLISH LEGAL TERMINOLOGY IN THE $19^{\mathrm{TH}}$ CENTURY
}

This paper aims to discuss the terminological influence of the Napoleonic Code on Polish legal terminology. Five major theses are formulated and supported by selected examples from two 19th century translations of the Code into Polish. We claim that, firstly, the Napoleonic Code had a major impact on the Polonisation of Polish legal lexis in the 19th century, and secondly, that where Polish legal language bears evidence of the influence of the adaptation of the Napoleonic law it is in structural calques from French and not in an increase of French borrowings in the Polish legal language; moreover, we provide evidence that the Napoleonic Code led to the redefinition of previously used terms in the Polish legal system, and finally, that it had a crucial impact on the systematisation of Polish legal terminology in the 19th century leading to its more contemporary character, closer to modern demands. The study contributes to a broader comparative analysis of the role of the Code in the history of shaping and transforming the terminological systems across national languages.

\section{Introduction}

The Napoleonic Code is widely considered to be of exceptional importance in the history of European law and modern states, “[...] uważany jest dziś za jedno 
z największych osiągnięć sztuki legislacyjnej i jako prawny fundament nowoczesnego społeczeństwa [it is considered as one of the greatest achievements of legislative art and as the legal foundation of modern society]" (Wielomski 2008: 201, own translation ${ }^{1}$ ). Its creation was motivated by the socio-economic changes connected with the French Revolution and the efforts to codify civil law in France. It was as Napoleon Bonaparte who was the initiator of the undertaking called Le Code Civil des Français (also referred to as Code Civil, Code Napoléon, Code Napoléonien), which started in 1800 to be completed and officially enacted in 1804.

The influence of the Napoleonic Code on legal systems of various countries was widely commented on ${ }^{2}$ (Chatillon 2002; Horie 2014), but the influence of the French legal terminology used in the Napoleonic Code on the legal terminology of individual states has not received much attention. This gap in legal linguistic research calls to be filled, as comparative analyses regarding the relationship of individual terminological systems in different languages to the French terminology used in the Code could bring to light new findings (Sacco 1999). Moreover, the analysis of the relationship between legal terminologies across national languages from a historical perspective may be useful for synchronic linguistic studies of contemporary terminology systems (Kierzkowska 1994; Bergenholtz, Tarp 2003; Cornu 2005; Ferran Larraz 2011; Lemmens 2011; Bissardon 2013; Cornu 2016, Lerat 2017).

Polish legislation was among the legal systems that were significantly influenced by the Napoleonic Code. The history of this influence began with the Duchy of Warsaw (Fr Duché de Varsovie), which was created in 1807 from Polish lands annexed in the 1790s by three powers of that time: Russia, Prussia and Austro-Hungary. As Poland did not exist as a fully independent national state since 1795, the Duchy of Warsaw was one of the attempts to restore Polish independence in some form. Formally a free state, in reality it was subordinate to the French Empire ruled by Napoleon Bonaparte. The Duchy of Warsaw was organised in a French way in terms of administration, with top positions held by French residents and military commanders. Although, as a Polish historian

All translations from Polish used in this article are own translations.

2 See articles in Revue internationale de droit comparé. Vol. 2 N4, Octobre-décembre 1950 (Revue 1950). for the discussion of the Napoleonic Code and its influence on legal systems of different countries. 
Jerzy Topolski (1994: 210) put it, the Duchy was "niesłychanie wyzyskiwane przez Napoleona [extremely heavily exploited by Napoleon]" - mostly on the economic level, it functioned as an efficient state that could maintain a 30-thousand army. After the defeat of Napoleon and the agreements of the Congress of Vienna in 1815, the Duchy was abolished, with a part of it transformed into the so-called Kingdom of Poland, linked by a personal union to the Russian Empire (Topolski 1994: 210-211).

In 1807, Napoleon granted the Duchy of Warsaw a constitution, and with it the Code Civil as a binding law. Art. 69 of the Constitution proclaimed that "Kodeks Napoleona stanowić będzie prawo Księstwa Warszawskiego [Napoleon's Code will constitute the law of the Duchy of Warsaw]" (Sójka-Zielińska 2007: 196). The introduction of the Napoleon's Code in the Duchy of Warsaw is considered to be a groundbreaking event by Polish law historians. It should be noted, however, that at the time it was perceived as controversial. In Poland, regulations of the Code were foreign law, diverging from the Polish legal traditions which had medieval origins. The Napoleon's Code was perceived as 'imposed'. Stanisław Posner (1912: 220) wrote that it meant breaking with sacred tradition and century-old practice. Despite the abolishment of the Duchy of Warsaw 8 years after its creation, the provisions of the Code, while amended to some extent, remained in force in the Russian-controlled Kingdom of Poland created by the Congress of Vienna in 1815. Further fate of the Polish nation, subject to the jurisdiction of foreign powers, meant that during the nineteenth century the attitude towards the Code changed radically. Napoleon's law started to be considered native law, being - as Sójka-Zielińska, a historian, writes - “jedyną wyspą polskości w morzu carskiego prawodawstwa, trwałym świadectwem naszej narodowej odrębności [the only island of Polishness in the sea of tsarist legislation, a permanent testimony to our national separateness]" (Sójka-Zielińska 2007: 200). The Code began to be treated as an expression of national identity of Poles and a witness to the ties with Western Europe. After Poland regained independence in 1918, the provisions of the Code constituted a point of reference for the law then adopted, and some regulations remained in force even until 1946 (Wołodkiewicz 2008: 12).

Our historical and linguistic interests revolve around the impact of the Napoleonic Code translations on Polish legal terminology. The introduction of French 
law required an adaptation of French institutions to Polish realities and the adaptation of existing Polish legal terminology, which supported a different political system, to the concepts of French law. Legal historians discuss the struggle between what is considered to be traditional and modern in legal terminology (Rosner 2008: 271). However, the issue of transformations within the terminology in the field of law after the introduction of the Napoleon's Code has not been much discussed in the Polish linguistics literature. It has been only recently that a team of linguists from Łódź, Poland, led by Ewa Woźniak, initiated research in this area (Woźniak and Zarębski 2016a; Woźniak and Zarębski 2016b; Woźniak and Wismont 2016; Woźniak and Zarębski 2018; Wismont 2018), thus becoming a part of a wider trend of investigations on the transformation of legal terminology caused by the influence of the Napoleonic Code within various national languages.

This paper aims to discuss the terminological influence of the Napoleonic Code on Polish legal terminology, to frame it in historical and linguistic discourse on a larger scale, and to show the scale of the influence. With legal historians emphasizing the importance of the Code in shaping the modern language of law, and especially legal terminology (Rosner 2007; Betańska 2011), it seems important that also language historians speak on the linguistic heritage of the Napoleonic Code from their own perspective. In this article, we focus on developmental trends in Polish legal terminology as derived from the translation of Code Civil.

Our research hopes to contribute to a broader comparative work on the role of the Code in the history of shaping and transforming the terminological systems of various national languages.

\section{Method}

Our research is based on a corpus composed of Polish translations of the Napoleonic Code of two authors. The first translation, rendered by Father Franciszek Ksawery Szaniawski was commissioned to him by Feliks Łubieński, who was the Minister of Justice in the Duchy of Warsaw at the time. The first edition of Szaniawski's Napoleonic Code in Polish, supplemented by commentary by 
the translator (see the source list: KN2) appeared in 1808. It was ordered for provisional use in the judiciary, but - if in doubt - judges were advised to refer to the French original. Upon the recognition of the imperfections of Szaniawski's translation, Łubieński asked the members of the scientific society (Society of Friends of Sciences) and lawyers from the Krakow Academy to commence works aiming at improving it. The scale of the difficulties and controversies accompanying the proofreading of the translation was such, that no final version could be agreed on. Szaniawski's translation had several editions (each with slight modifications), including those from 1809, 1810, 1811, and an 1813 trilingual edition: Polish, French and Latin (see source list: KN3). The author of the second translation, also commissioned by Minister Łubieński, was Ksawier Michał Bohusz (see abbreviation list KN1) (Smoleński 1925; Grynwaser 1951; Rosner 2007: 10-13). Neither of the two translations obtained the status of an official translation, but - as shown by our previous findings (Woźniak and Zarębski 2016b) - it was Szaniawski's translation that had a greater impact on Polish legal terminology and was much more widely used, which is evident from numerous editions. The two translators - Szaniawski and Bohusz, significantly differed in their preferences in the selection of Polish equivalents for French terms in the Code: Szaniawski was a proponent of introducing neologisms, not burdened by the current semantics, while Bohusz opted for using traditional terminology in the new meanings appearing in the Code.

The material from the above-mentioned Polish translations of the Code has been subjected to systematic observation using contrastive linguistic methods (Polish translations were compared with the French original) in order to extract individual differences and similarities in Polish equivalents of French terms. Equivalence was manifested in the use of semantic equivalents, neosemanticisms, semantic borrowings, and structural calques, each to a different degree in each translation. The research procedure also intended to indicate which text had a stronger impact on the development of nineteenth-century Polish legal terminology. Comparative analyses confirmed that it was Szaniawski's translation, which means that the translation strategy he represented dominates in the development tendencies of Polish legal lexis in the 19th century. 


\section{Theses}

In this part of the article, five theses are formulated and supported by selected examples.

\section{Thesis I: The Napoleonic Code had a major impact on the Polonisation of Polish legal lexis in the 19th century}

Between the 16th and 18th century Polish legal terminology was dominated by borrowings from Latin. Apart from borrowings, original Latin phrases and sentences (especially dicta) were included in Polish texts. The use of Latin reflected reference to the tradition of Roman law and it seems to have been strengthened by increasingly good knowledge of this system coupled with the prestige of Latin, which was the language of the intellectual and social elite in Poland (Sobczykowa 2007). It was not until the mid 18th century and the ideologies of the Age of Enlightenment that national languages began to be appreciated and was expected to be also used in legal documents. A demand was formulated regarding the translation of the foreign words and phrases used in legal texts into Polish and the exclusive use of Polish language in constituting the law as well as its use in administrative-judiciary practice (Woźniak, 2015: 26-27). The atmosphere of ascribing prestige to the national language had an impact on the attitude of the Napoleonic Code translators. As a consequence, foreign quotes were completely eliminated from the translations of the Code. What is more, Latinisms, even if already well established in use, were not employed even if the French original text suggested it. This tendency can be illustrated by the following examples: adopcja (English adoption, French l'adoption, Latin adoptio), akcja (English action, French l'action, Latin actio), cesja (English cession, French la cession, Latin cessio), donacja (English donation, French la donation, Latin donatio), donator (English donor, French le donateur, Latin donator), egzekutor (English executor, French l'exécuteur, Latin exsecutor), emancypacja (English emancipation, French l'emancipation, Latin emancipatio), inskrypcja (English inscription, French l'inscription, Latin inscriptio), kontrakt (English contract, French le contrat, Latin contractus), obligacja (English obligation, French obligation, Latin obligatio), preskrypcja (English prescription, French 
la prescription, Latin prescriptio), redukcyja (English reduction, French la réduction, Latin reductio), separacja (English separation, French la séparation, Latin separatio), tutor (English tutor, French le tuteur, Latin tutor). There was a tendency to apply native terms as equivalents to those terms. Therefore, the respective translations into Polish were as follows: przysposobienie (English adoption), sprawa (English case), ustapieniel zrzeczenie się (English waiver), darowizna (English donation), darujacy (English donor), wykonawca (English executor), usamowolnienie (English emancipation), zapis (English provision), umowa (English contract), zobowiazanie (English obligation), przedawnienie (English prescription), zmniejszenie (English reduction), rozłaczenie (English separation), opiekun (English curator).

\section{Thesis II: Polish legal language bears evidence of the influence of the adaptation of the Napoleonic law in structural calques from French.}

Structural calques created with elements of the Polish language system - according to their creators - the translators, complied with the requirement of using the native language, which means that they were in accordance with language norms of the Enlightenment. Consequently, a number of equivalents of the original French terms used in the Code were formed by copying the structure and using Polish lexis to express the meaning, including such terms as dzieci naturalne (English lit. children natural, French les enfants naturels) to describe children born outside marriage, wstępny (English ancestral, French ascendants) and zstępny (English descendent, French descendants) to name the degree of relationship among generations, or rada familijna (English Family Council, French le conseil de famille).

The term dzieci naturalne (English natural children) replaced a traditional expression dzieci z nieprawego toża (English illegitimate children) previously used in the Polish legal system. Today, this term is no longer recognised in the civil law and has been replaced by a more semantically clear phrase dzieci spoza zwiqzku matżeńskiego (English children born outside marriage). However, the term dzieci naturalne was still in use in the first half of the 20th century during the period between the wars (1918-1939), as evidenced by an article title which appeared in the Palestra journal in 1928: Uprawnienie dzieci naturalnych przez 
postanowienie Prezydenta Rzeczypospolitej (English Legitimization of natural children by the resolution of the President of the Republic of Poland). To this day the term is used in Canon Law (Woźniak 2017).

An institution previously unknown to the Polish legal system, which was introduced in accordance with the Napoleonic Code was rada familijna (English Family Council). It was “organ kolegialny, składający się z członków rodziny, sprawujących nadzór nad opieką pod przewodnictwem sędziego pokoju [a collegiate body made up of family members and having supervision over custody under the leadership of the Justice of the peace]" (Machut-Kowalczyk 2014: 29). The lexical meaning of the term indicates that it is a calque from the French expression le conseil de famille: "Rada familijna złożona będzie z sześciu krewnych lub powinowatych, w połowie po mieczu, w połowie po kądzieli [The Family Council will consist of six relatives or in-laws chosen equally from patrilineal and matrilineal side]" (KN1: par. 407: 46). "Rada familijna złożona będzie, nie obeymuiąc Sędziego Pokoiu, z sześciu krewnych lub powinowatych w połowie ze strony ojcowskiej, w połowie ze strony macierzyńskiej [The Family Council, besides the Justice of the peace, will consist of six relatives or in-laws, half of them from the father's side and half of them from the mother's side]" (KN3).

All of the abovementioned structural calques entered the Civil Code of the Kingdom of Poland (see the abbreviation list for KCKP): "Dzieci obowiązane sa dawać alimenta rodzicom i innym wstępnym w potrzebie zostającym [Children are obliged to provide maintenance for their parents and other ascendants who are in need]" (KCKP, par. 238, 128), "Między krewnemi, bliższy iest obowiązek bliższych co do stopnia, bliższy wstępnych aniżeli zstępnych [Among relatives, the duty is closer the closer the relation, it is closer for the ascendants than descendants]" (KCKP, par. 241: 129); "Gdy zwołana Rada familiyna utrzyma matkę przy opiece lub ią do niéy przywróci, winna iéy dodać koniecznie nowego iéy męża za współopiekuna [When the convened Family Council allows for the mother to be the guardian or reverses her into care, it should add her new husband as a joint guardian]" (KCKP, par. 362: 194). "Rada familiyna złożona będzie nie rachując Sędziego, z sześciu krewnych lub powinowatych (...) [The Family Council, besides the Justice of the peace, will consist of six relatives or in-laws (...)]" (KCKP, par. 375: 201). 
Such terms as Polish equivalents of ascendants (Polish wstępni) and descendants (Polish zstepni) started to be consistently used terms, and they can be found in current legal language in Polish.

The influence of French from the Napoleonic Code can be also seen in other phrases used in contemporary legal language, e.g. rozwiqzanie matzeństwa przez rozwód (English dissolution of marriage by divorce), which stems from la dissolution du marriage par la divorce in French) or żadać/żadanie rozwodu (English to demand/a demand for divorce) (French demander le divorce, demande en divorce). These new collocations introduced in the translations of the Code, continued to be used in the Civil Code of the Kingdom of Poland and other subsequent legal regulations (Woźniak and Wismont 2016).

It was Szaniawski who was an advocate of such structural calques as equivalents of the original French terms. He is ascribed the creation of the aforementioned phrases.

\section{Thesis III: The adaptation of French law did not result in an increase of French borrowings in the Polish legal language ${ }^{3}$.}

This thesis challenges the conclusion formulated by a law historian Ewa Betańska, who studied the influence of the Napoleonic Code on the Polish inheritance legal terminology (Betańska, 2013). The difference of opinion is a consequence of applying different criteria in considering a word a borrowing in this particular context. Most importantly, Betańska does not apply a chronological criterion and regards Latinisms that had already been assimilated in Polish before the Napoleonic Code was adapted, such as for example testament (English testament) or inwentarz (English inventory) to be Gallicisms as well. If borrowings were to be treated as a fact from the history of language then one of a few Gallicisms that should be treated as a semantic calque from French would be the word alimenty (English maintenancelalimony, French les alimens ${ }^{4}$ ) which was introduced in the Napoleonic Code to denote a new phenomenon which was to provide means of maintenance to those towards whom other people had any obligations. In fact,

\footnotetext{
3 A similar conclusion has been reached on the basis of divorce terminology (Woźniak and Wismont 2006).

${ }^{4}$ Aliment (French) in the 2nd meaning in plural aliments 'alimenta' (SFP).
} 
the word alimenty has been known in Polish since the $16^{\text {th }}$ century, however, its meaning used to be different - food, meal, nourishment (SPXVI, SJPXVII/ XVIII). As an indicator of a new legal terminology, it required to be described in more detail, as in the following example: "Dzieci powinny dawać na al i m enta, czyli na potrzeby życia (...) [Children should be provided alimony, that is the living necessities (...)]", (KN1, par. 205). This term was still in use in the Civil Code of the Kingdom of Poland: "Alimenta dostarczone bydź powinny tylko w stosunku do potrzeb osób prawo do nich maiących, i w stosunku do majątku obowiązanych ie dawać [Maintenance should be provided only for those who have the right to receive it, and should be equivalent to the amount of the estate of those who are to provide it]" (KCKP, par. 242). The term continues to be used in current general language with regard to legal obligation to provide means for a living, especially of parents to their children.

The avoidance of borrowings by the Code translators followed the Enlightenment demand to support native vocabulary.

\section{Thesis IV: The Napoleonic Code led to the redefinition of previously used terms in the Polish legal system.}

The use of old Polish terms in new meanings in the translation of the Napoleonic Code is particularly important, as it bears witness to thorough changes that took place at the time when the Code was introduced. It also proves that the Code was groundbreaking and influential to an extent which made abandoning the old semantics possible. We are thinking here of words such as prokurator (English prosecutor), rozwód (English divorce) or kurator (English curator). The most prominent example is the word prokurator (English prosecutor), which according to the old Polish legal system described "a proxy, an attorney, a barrister". However, since the Code, it has been used to describe a person fulfilling the opposite role in the trial, the role of a public prosecutor (Polish oskarzyciel publiczny) (Zajda 1990: 239; Zajda 2001: 164). The French codification also provides a clear delimitation for the use of the word rozwód (English divorce) which was previously used to denote the annulment of marriage (Polish uniewaznienie matżeństwa). The new definition 'rozwiązanie małżeństwa ważnie zawartego' [a dissolution of marriage that was legally formed] derived from the fact that the 
Napoleonic Code understood it differently to canon law - not as a sacrament but as a civil contract, which as any other contract, could be terminated (Woźniak and Wismont, 2016: 4-5). Another example is the term kurator (English curator), which the Code used to name the person that becomes a guardian of a pregnant woman after her husband's death. In the old Polish legal system, however, it was used to define a guardian of an adult who, for some reasons, cannot make decisions regarding themselves (Wismont, in print).

\section{Thesis V: The Napoleonic Code had a crucial impact on the systematisation of Polish legal terminology in the 19th century, which resulted in its more contemporary character closer to modern demands}

The Napoleonic Code brought the awareness of the need to systematise the Polish legal terminology so that it would follow French law. Szaniawski noticed the discrepancies between the state of Polish legal lexis and French standards, which he attributed to the difficulties in Code translation

W polskim języku nie mamy dotąd obszernej jurisprudencyi uczonym sposobem uporządkowanej, tem więc trudniej wyrazić w ojczystej mowie przepisy Kodeksu. W dawnych prawach polskich wiele łaciny mieściło się i różne wyrazy bez ścisłego ich oznaczenia na jedno wyobrażenie używanemi były.

[Polish language does not exhibit a clear jurisprudence and that is why it is difficult to express the rules of the Code in our native language. In the old Polish laws, there were many Latin terms that were not clearly defined and as a result different words could be used to describe a single phenomenon.]. (X.S. 1809: 55)

The translator points out to the lack of systematisation in the field of law-making and to polysemy and ambiguity of the used terms. This situation was a consequence of the previous organization of the legal system in Poland. Judges did not have theoretical knowledge. They were selected from among gentry during assemblies, and the selection process was based on their standing in the local community, as well as on their experience (Rosner 2007: 21). Consequently, the court procedure was precedent based and legal terms were used with the meaning ascribed by traditional usage without clear definition (X.S. 1809: 55). 
It was only the influence of the French legal culture that brought groundbreaking changes in the education of law-court administration. The implementation of the Napoleonic law brought the need to provide the courts with clerks knowledgeable in the field. To satisfy the need, a Law School was created in Warsaw in 1808; the graduates of the School were then recruited for administrative and legal positions. This change in education had a strong impact on the stabilisation of terminology: through legal education, the terms were learned (and used) in their defined, and not traditional meanings.

Efforts to reshape Polish legal terminology so that it would resemble the French ideal in terms of consistency and lack of ambiguity, can be seen in the approach to translation, with a tendency to use one Polish equivalent for a French term from the original text. The juxtaposition of the Polish terminology with the French in the process of translation brought the awareness that using one word as an indicator of one idea is an example of a higher legal culture. Polish translations of the Napoleonic Code provide a demarcating line for the usage of synonymous clusters in legal texts, which had been a common practice between the $16^{\text {th }}$ and $18^{\text {th }}$ century and which had its roots in the medieval translations of verdicts and codes (Woźniak 2018). Within one translation, e.g., the one by Szaniawski or the one by Bohusz, not only are efforts made to decrease the use of synonymy, but also to provide relations within the conceptual framework through the form (linguistic shape) of the term. For example, Szaniawski is consistent in translating the French la tutelle officieuse as opieka dobroczynna (English unofficial guardianship) (KN2 and KN3), while Bohusz opts for opieka uczynna (KN1). This way of translation is also maintained for a related term un tuteur officieux, which Szaniawski translates, in accordance to his opieka dobroczynna, as opiekun dobroczynny (English unofficial guardian) (KN2 and KN3) and Bohusz, similarly to his opieka uczynna renders it as opiekun uczynny (English unofficial guardian) (KN1). This way a conceptual framework of related terms and related phrases is built, which provides information on how those terms are actually related: opiekun uczynny (English unofficial guardian) is a person who provides opieka uczynna (English unofficial guardianship) or, in a different rendering, opiekun dobroczynny (English unofficial guardian) is a person who provides opieka dobroczynna (English unofficial guardianship). People providing other types of guardianship (which is more complex according to the Code than it was in the old Polish law) have their own names: opiekun przydany (English ascri- 
bed guardian) (KN2 and KN3) (or dodatkowy in KN1) (English additional), współopiekun (English joint guardian), zaopiekun (English caregiver), kurator (English public guardian) (Wismont, in print). Legal concepts and their assigned terms begin to form a system of relations. The term does not exist in isolation but in relation with other equivalent terms (cohyponyms) as well as subordinate and superordinate terms.

\section{Conclusions}

The arguments supporting the theses put forward in the previous sections lead to a number of conclusions, which are presented in a synthetic form below.

1. The significance of the Napoleonic Code to the development of Polish legal language is clear for the following reasons:

a) It was the first codified law that was applied in the administrative-judiciary practice in vast areas of Polish lands.

b) A relevant factor determining the role the Code played in the Polish legal system is the long-term application of its rules, which lasted even during the law-making after Poland regained its independence in 1918. At first, it was reluctantly received as foreign and breaking with the Polish legal tradition. With time, however, it began to be treated as an expression of national identity and an evidence for connections with Western civilization. Some of the Napoleonic Code regulations lasted until 1946.

c) The necessity for adaptation of foreign legal terms, the need for making decisions regarding earlier forms in terms of terminology - as continuity, re-evaluation or rejection and adoption of new solutions - all of these circumstances, caused by the implementation of the Napoleonic Code, influenced the stock and semantics of legal lexis. The adaptation of new terms required providing their definitions and clarifications as well as differentiating between the terms with similar meanings, which allowed the Polish legal terminology to achieve a higher level of systematisation. 
2. The implementation of the Napoleonic Code brought about crucial transformations when it comes to Polish legal terminology in the 19th century. The most clearly marked is the change regarding the Polonisation of the legal lexis. Codifiers who can choose from numerous terminological doublets, which are a legacy of the previous age, have a tendency to opt for a native variety of the terms (for example darowizna instead of donacja (English donation) or przysposobienie instead of adopcja (English adoption) and so on). However, if a borrowing is selected, it is justified by the need to differentiate between the terms, as in the case of the words opiekun (English caregiver) and kurator (English guardian). Selecting a foreign term can also be motivated by the lack of a native equivalent (casus alimenty (English maintenance)). The 'cult of nativeness' (preference for native vocabulary) in creating new terms can be also observed in the tendency to avoid Gallicisms, and particularly in the lack of continued usage of those Polish borrowings from Latin which were found in the French original text. In other words, the French terms used in the original text did not cause their equivalents to emerge (equivalents which were previously borrowed from Latin). Unlike borrowings, however, lexical calques, which were created by transferring French phrases with the use of Polish morphemes, according to the 19th century codifiers complied with the requirement of native equivalents (this way, such phrases as dzieci naturalne (English natural children), wstępny (English ancestor), zstępny (English descendant), żqdać rozwodu (English to demand divorce), rozwiqzanie matzeństwa przez rozwód (English a dissolution of marriage by divorce) and others were formed). The editors of legal acts of the day clearly break away from a general tendency to succumb to the French influence, which left many 19th century Gallicisms in Polish vocabulary across semantic fields. Researchers studying French borrowings in Polish point to the19th century as the height of the influence, seen mostly in the increase of the scope and fields in which they are found (Walczak 1986; Walczak 2004). The fact that the codifiers of the legal terminology did not succumb to the French influence proves their more than average linguistic awareness. 


\section{Sources}

KCKP = Kodeks cywilny Królestwa Polskiego [The Civil Code of the Kingdom of Poland], Dziennik Praw 1826 [Legal journal 1826], vol. 10, no. 41.

KN1 = Kodeks Napoleona (...) przekładania Ksawiera Michała Bohusza (...) z przyłaczeniem słowniczka wyrazów pewnych polskich odpowiadajacych francuskim (...) [The Napoleonic Code (...) translations by Ksawery Michat Bohusz (...) supplied with a dictionary of some Polish words corresponding to the French]. Drukarnia Wiktora Dąbrowskiego. Warszawa 1810. http://mbc.cyfrowemazowsze.pl/dlibra/docmetadata?id =757\&from=\&dirids=1\&ver_id=\&lp=1\&QI= (accessed 31 March 2019).

KN2 = Kodeks Napoleona z przypisami [The Napoleonic Code with annotations], vol. I. Drukarnia Księży Pijarów. Warszawa 1808. https://www.bibliotekacyfrowa.pl/dlibra/ show-content/publication/edition/6697?id=6697 (accessed 31 March 2019).

KN3 = Kodex Napoleona. Code Napoléon. Codex Napoleonis [The Napoleonic Code]. Drukarnia Rządowa. Warszawa 1813. http://pbc.biaman.pl/dlibra/doccontent?id=23691 (accessed 31 March 2019).

SFP = Matkowski, Zygmunt; Ciesielska-Borkowska; Stefanja, Stownik encyklopedyczny francusko-polski i polsko-francuski. Część pierwsza francusko-polska [Encyclopeadic French-Polish and Polish-French dictionary. Part One: French-Polish]. Księgarnia Polska Bernarda Połanieckiego we Lwowie. Lwów - Warszawa 1928.

SJPXVII/XVIII = Elektroniczny słownik języka polskiego XVII i XVIII wieku [Electronic dictionary of the Polish language of the 17th and 18th century], Polska Akademia Nauk, Instytut Języka Polskiego. https://sxvii.pl/ (accessed: 15 March 2019).

SPXVI = Stownik polszczyzny XVI wieku [Dictionary of the Polish language of the 16th century]. Vol. 21. Zakład Narodowy im. Ossolińskich. Wrocław 1982. Vol. 33. Instytut Badań Literackich PAN. Warszawa 2009. https://kpbc.umk.pl/dlibra/publication/17781 (accessed 15 March 2019).

\section{References}

Bergenholtz, Henning; Tarp, Sven (eds.). 1995. Manual of Specialized Lexicography. Benjamins. Amsterdam.

BetańsKa, EwA. 2013. Terminologia prawa spadkowego $w$ aspekcie porównawczym francusko-polskim [Terminology of inheritance law in the French-Polish comparative aspec.]. PhD diss. University of Adam Mickiewicz Poznań. https://repozytorium.amu. edu.pl/handle/10593/6508 (accessed 17 November 2016).

BetańsKa, Ewa. 2011. Code Civil Français et Kodeks Cywilny Polonais [The French 
Code Civil and the Polish Civil Code]. Comparative Legilinguistics 8. 9-18. https:// pressto.amu.edu.pl/index.php/cl/article/view/7780 (accessed 17 November 2016).

BisSARDON, SÉBASTIEN. 2013. Guide du langage juridique: vocabulaire-pièges et difficultés [Guide to legal language: vocabulary - pitfalls and difficulties]. LexisNexis (Litec). Paris (4e éd.).

Chatillon, StÉPhane. 2002. Droit et langue [Law and language]. Revue internationale de droit comparé 54 N³. 687-715. doi.org/10.3406/ridc.2002.17804.

CORnu, GÉRARD. 2005. Linguistique juridique [Legal Linguistics]. Montchrestien. Paris (3e éd.).

CORnu, GÉRARD. 2016. Vocabulaire juridique [Legal vocabulary]. PUF - Quadrige. Paris (11e éd.).

Ferran Larraz, Elena. 2011. Estatismo y dinamismo de la terminología jurídica en el ámbito de los documentos de transmisión de bienes [Statism and dynamism of legal terminology in the field of asset transfer documents]. Terminology. International Journal of Theoretical and Applied Issues in Specialized Communication 17(2). 224-248. doi. org/10.1075/term.17.2.03fer.

Grynwaser, Hipolit. 1951. Kodeks Napoleona w Polsce [Napoleon's Code in Poland]. Pisma 1. 13-172. Zakład Narodowy im. Ossolińskich - Wydawnictwo. Wrocław.

KierzKowsKa, DANuta. 1994. Standardization of Polish legal terminology. Terminology. International Journal of Theoretical and Applied Issues in Specialized Communication 2(1). 129-139. doi.org/10.1075/term.2.1.07kie.

Lemmens, Koen. 2011. The slow dynamics of legal language: Festina lente? Terminology. International Journal of Theoretical and Applied Issues in Specialized Communication. The dynamics of terms in specialized communication: An interdisciplinary perspective 17. Issue 1. 74-93. doi.org/10.1075/term.17.1.05lem.

Lerat, Pierre. 2017. Dictionnaire Juridique Plurilingue [Plurilingual Legal Dictionary]. La Maison du dictionnaire. Paris.

Machut-KowalczyK, JoAnna. 2014. Rada familijna pod powaga sadu pokoju w świetle akt łęczyckich, zgierskich $i$ tódzkich z lat 1809-1876 [Family council under the authority of the court of peace in the light of the Eeczyca, Zgierz and Lódz files from 1809-1876]. Head Republic. Łódź. http://dspace.uni.lodz.pl:8080/xmlui/bitstream/ handle/11089/11376/Doktorat\%20nr\%207.pdf?sequence=1\&isAllowed=y (accessed 16 November 2016).

Posner, StanisŁaw. 1912. Polska a Kodeks Napoleona [Poland and the Napoleonic Code]. Krytyka 35. 13-24. https://www.wbc.poznan.pl/dlibra/show-content/publication/ edition/86278?id=86278 (accessed 16 November 2016).

REVue 1950. = Revue internationale de droit comparé 2 no. 4. Octobre-décembre 1950. https://www.persee.fr/issue/ridc_0035-3337_1950_num_2_4 (accessed 10 November 2019). 
Rosner, ANNA. 2007. Zmagania z językiem prawa. Przykład polskiego przekładu Kodeksu Napoleona w Księstwie Warszawskim [Struggles with the language of law. An example of the Polish translation of the Napoleonic Code in the Duchy of Warsaw]. Wspótczesny język prawny i prawniczy [Contemporary legal language and language of law]. Eds. Niewiadomski, Adam et al. Wydział Prawa i Administracji, Uniwersytet Warszawski. Warszawa. 9-22.

Rosner, Anna. 2008. Pierwsze polskie thumaczenia Kodeksu Napoleona [On the first Polish translations of the Napoleonic Code]. Kodeks Napoleona. Historia i wspótczesność [Kodeks Napoleona. Historia i wspótczesność]. Ed. Sójka-Zielińska, Katarzyna. Wydawnictwo Prawnicze LexisNexis. Warszawa. 271-294.

SACCO, Rodolfo. 1999. Langue et droit. Les multiples langues du droit européen uniforme [Language and law. The multiple languages of uniform European law]. L'Harmattan. Torino.

SmOLEŃSKI, WŁadysŁaW. 1925. Spory o przekład polski Kodeksu Napoleona [Disputes over the Polish translation of the Napoleonic Code.]. Studia historyczne [Historical studies]. Gebethner i Wolf. Warszawa. 232-238.

Sobczyкowa, JoAnna. 2007. Łacina w oczach dawnych Polaków [Latin in the eyes of Poles]. Przeglad Humanistyczny 1. 105-115.

SóJKa-ZielińsKa, Katarzyna. 2007. Kodeks Napoleona. Historia i współczesność [Napoleonic Code. History and the present day]. Wydawnictwo Prawnicze LexisNexis. Warszawa.

Topolski, Jerzy. 1994. Historia Polski [History of Poland]. Kopia. Warszawa.

WalczaK, Bogdan. 1986. Galicyzmy w polszczyźnie na tle historii związków polsko-francuskich [Galicianism in Polish against the background of the history of PolishFrench relations]. Rozprawy Komisji Językowej Łódzkiego Towarzystwa Naukowego 32. 291-297.

WALCZAK, Bogdan. 2004. Chronologia wpływów obcych w dziejach języka polskiego w świetle nowszych prac historycznojęzykowych [The chronology of foreign influences in the history of the Polish language in the light of newer historical and linguistic works]. W kreggu wiernej mowy [In a circle of faithful speech]. Eds. Wojtak, Maria et al. Wydawnictwo UMCS. Lublin. 409-417.

WielomsKi, AdAm. 2008. Krytyka Kodeksu Napoleona we Francji w XIX wieku [Criticism of Napoleon's Code in France in the 19th century]. Doktrina. Studia SpolecznoPolityczne 5. 201-216.

Wismont, Magdalena. 2018. Osoby w sądzie. Określenia osób w sprawie rozwodowej na przykładzie tłumaczeń Kodeksu Napoleona [People in court. Definitions of persons in a divorce case on the example of translations of the Napoleonic Code]. Filologia jako porzadkowanie chaosu. Studia nad językiem i tekstem [Philology as Ordering Chaos. 
Studies on Language and Text]. Eds. Woźniak, Ewa et al. Wydawnictwo Uniwersytetu Łódzkiego. Łódź. 431-442.

Wolodkiewicz, Witold. 2008. 200 lat Kodeksu Napoleona w Polsce - od nienawiści do miłości [200 years of Napoleonic Code in Poland - from hatred to love]. Palestra 1-2. 141-146.

WoŹNIAK, EwA. 2015. Ciągłość i zmiana - o języku urzędowym w dobie nowopolskiej [Continuity and change - on the official language in the era of New Poland]. Poradnik Językowy 3. 26-41.

WoźNIAK, EwA. 2017. Od dzieci z nieprawego łoża do dzieci nieślubnych. Z dziejów polskiej terminologii prawnej [From illegitimate children/ z nieprawego łoża to illegitimate children/ dzieci nieślubne. From the history of Polish legal terminology] LingVaria 1(23). 151-164. doi.org/10.12797/LV.12.2017.23.10.

WoźNIAK, EwA. 2018. O funkcji szeregów synonimicznych w dawnych polskich tekstach prawnych [On the function of synonymous series in old Polish legal texts]. Poradnik Językowy 7. 75-84.

Woźniak, Ewa; Wismont, Magdalena. 2016. "Stare" i "nowe" w polskiej terminologii prawnej 1 poł. XIX w. (na przykładzie terminologii dotyczącej rozwodów) ['Old' and 'New' in Polish legal terminology of the first half of the 19th century (on the example of divorce terminology)]. Issledovanija po Slavianskim Jazykam 21 (1)1. 1-20.

WoźNIAK, Ewa; ZaręBSKi, RAFAŁ. 2016a. Kodeks Napoleona w dziejach języka urzędowego w Polsce - rekonesans badawczy [Napoleonic Code in the history of the legal language in Poland - a research reconnaissance]. Język Polski 1. 46-58.

WoŹNIAK, EwA; ZARĘBSKI, RAFAŁ. 2016b. Kontynuacja vs innowacja. Drogi rozwoju polskiej terminologii administracyjno-prawnej po wprowadzeniu Kodeksu Napoleona [Continuation vs. innovation. Roads for the development of Polish administrative and legal terminology after the introduction of the Napoleonic Code]. Prace Filologiczne 69. 535-547.

WoŹNIAK, EWA; ZARĘBSKI, RAFAŁ. 2018. O (nie)przydatności źródeł leksykograficznych w badaniach XIX-wiecznej terminologii prawnej [About (un)usefulness of lexicographic sources in the study of nineteenth-century legal terminology]. Język Polski 4. 59-69. dx.doi.org/10.31286/JP.98.4.6.

X.S. 1809. O tłumaczeniu Kodeksu Napoleona w polskim języku [On the Napoleonic Code translations in Polish]. Pamiętnik Warszawski 3. 52-60. https://crispa.uw.edu.pl/ object/files/322188/display/PDF (accessed 10 November 2019).

Yuki, HaRI. 2014. L'Influence du Code Napoleon sur le code civil japonais [Influence of the Napoleonic Code on the Japanese Civil Code]. Comparative legilinguistics. International Journal for Legal Communication 19 (2014). 155-213. doi.org/10.14746/ cl.2014.19.03. 
Zajda, AleKsander. 1990. Staropolska terminologia prawnicza (do 1500 r.) [Old Polish legal terminology (up to 1500)]. Wydawnictwo Uniwersytetu Jagiellońskiego. Kraków.

Zajda, Aleksander. 2001. Studia z historii polskiego stownictwa prawniczego i frazeologii [Studies in the history of Polish legal vocabulary and phraseology]. Wydawnictwo Uniwersytetu Jagiellońskiego. Kraków.

\section{Napoleonov zakonik i poljska pravna terminologija tijekom XIX. stoljeća}

\section{Sažetak}

U članku se raspravlja o utjecaju Napoleonova zakonika na poljsku pravnu terminologiju. Formulirano je pet osnovnih teza, potkrijepljenih odabranim primjerima iz dvaju poljskih prijevoda Zakonika iz XIX. stoljeća. Može se zaključiti da je Napoleonov zakonik u znatnoj mjeri utjecao na eliminaciju latinizama i latinskih termina te na njihovu zamjenu domaćim ekvivalentima, a zatim i da francuske terminološke posuđenice obično imaju karakter strukturnih prevedenica, a ne leksičkih posuđenica. Štoviše, pokazalo se da je Napoleonov zakonik doveo do redefiniranja termina koji su prije bili u uporabi u poljskome pravnom sustavu i da je imao odlučujući utjecaj na usustavljivanje poljske pravne terminologije tijekom XIX. stoljeća, dovodeći do njezine modernizacije, koja je u skladu i sa suvremenom situacijom. Studija je dio šire poredbene analize uloge Zakonika u povijesti oblikovanja i preoblikovanja terminološkog sustava u narodnim jezicima.

Key words: legal terminology, Napoleonic Code translation, developmental trends in legal terminology, Polish legal terminology

Ključne riječi: pravna terminologija, prijevod Napoleonova zakonika, razvojni trendovi u pravnoj terminologiji, poljska pravna terminologija 